\title{
Flavobacterium anhuiense sp. nov., isolated from field soil
}

Correspondence
Ren Lai
rlai72@njau.edu.cn

\author{
Huan Liu, ${ }^{1}$ † Rui Liu, ${ }^{1}$ † Shou-Yun Yang, ${ }^{1}+$ Wei-Kai Gao, ${ }^{1}$ \\ Chong-Xing Zhang, ${ }^{1} \mathrm{Ke}-$ Yun Zhang ${ }^{1}$ and Ren Lai ${ }^{1,2}$
}

${ }^{1}$ Key Laboratory of Microbiological Engineering of Agricultural Environment, Ministry of Agriculture, Life Sciences College of Nanjing Agricultural University, Nanjing, Jiangsu 210095, PR China

${ }^{2}$ Biotoxin Department of Key Laboratory of Animal Models and Human Disease Mechanisms, Kunming Institute of Zoology, Chinese Academy of Sciences, Kunming, Yunnan 650223, PR China
The genus Flavobacterium (Bergey et al., 1923) was emended by Bernardet et al. (1996) to include Gram-negative, aerobic, predominantly gliding, yellow-pigmented bacteria with DNA G $+\mathrm{C}$ contents in the range $32-37 \mathrm{~mol} \%$ and MK-6 as the major respiratory quinone. Flavobacterium is the type genus of the family Flavobacteriaceae, phylum Bacteroidetes (previously, the Cytophaga-Flavobacterium-Bacteroides group) (Ludwig \& Klenk, 2001; Bernardet et al., 2002). Flavobacterium strains occur in soil, fresh water and marine habitats. Many species are cold-adapted, whilst others are pathogenic to freshwater fish (Bernardet \& Bowman, 2006). The genus Flavobacterium currently comprises 49 recognized species, including the recently described species Flavobacterium defluvii (Park et al., 2007), Flavobacterium aquidurense and Flavobacterium hercynium (Cousin et al., 2007), Flavobacterium terrigena (Yoon et al., 2007), Flavobacterium terrae and Flavobacterium cucumis (Weon et al., 2007).

A yellow-pigmented bacterial strain, designated $D 3^{T}$, was isolated from a field-soil sample from Anhui Province, PR China. Strain $\mathrm{D}^{\mathrm{T}}$ was isolated by using the dilution-plating

†These authors contributed equally to this paper.

The GenBank/EMBL/DDBJ accession number for the 16S rRNA gene sequence of strain $\mathrm{D}^{\top}{ }^{\top}$ is EU046269.

Transmission electron micrographs of strain $\mathrm{D}^{\top}$ are available with the online version of this paper. technique on Luria-Bertani (LB) agar $\left(1^{-1}: 5\right.$ g yeast extract, $10 \mathrm{~g}$ tryptone, $10 \mathrm{~g} \mathrm{NaCl} ; \mathrm{pH} 7.0)$ incubated at $30{ }^{\circ} \mathrm{C}$ and was cultivated routinely in LB agar or in LB broth at the same temperature.

The primers used for PCR amplification of the 16S rRNA gene were 5'-AGAGTTTGATCCTGGCTCAG-3' (forward)

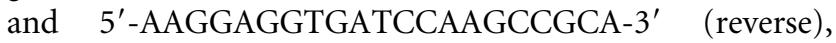
corresponding to positions $8-27$ and 1521-1540, respectively, in the 16S rRNA gene sequence of Escherichia coli (Brosius et al., 1978). The 1398 bp sequence of strain $\mathrm{D}^{\mathrm{T}}$ was compared with available sequences retrieved from GenBank by using the BLAST program (http:// www.ncbi.nlm.nih.gov/blast/) to determine an approximate phylogenetic affiliation. A phylogenetic analysis was performed by using the software packages PHYLIP (Felsenstein, 1993) and MEGA, version 3.1 (Kumar et al., 2001), after multiple alignment of the data by CLUSTAL_X (Thompson et al., 1997). Distances (with distance options according to the Kimura two-parameter model; Kimura, $1980,1983)$ and clustering were based on the neighbourjoining (Saitou \& Nei, 1987) and maximum-likelihood (Felsenstein, 1981) methods. Bootstrap analysis (1000 replications) was used to evaluate the topology of the neighbour-joining tree (Felsenstein, 1985). This tree (Fig. 1) showed that strain $\mathrm{D} 3^{\mathrm{T}}$ grouped with Flavobacterium species. It shared 96.7, 96.4, 95.1, 94.8 and $94.8 \% 16 \mathrm{~S}$ rRNA gene sequence similarity with $F$. defluvii, 


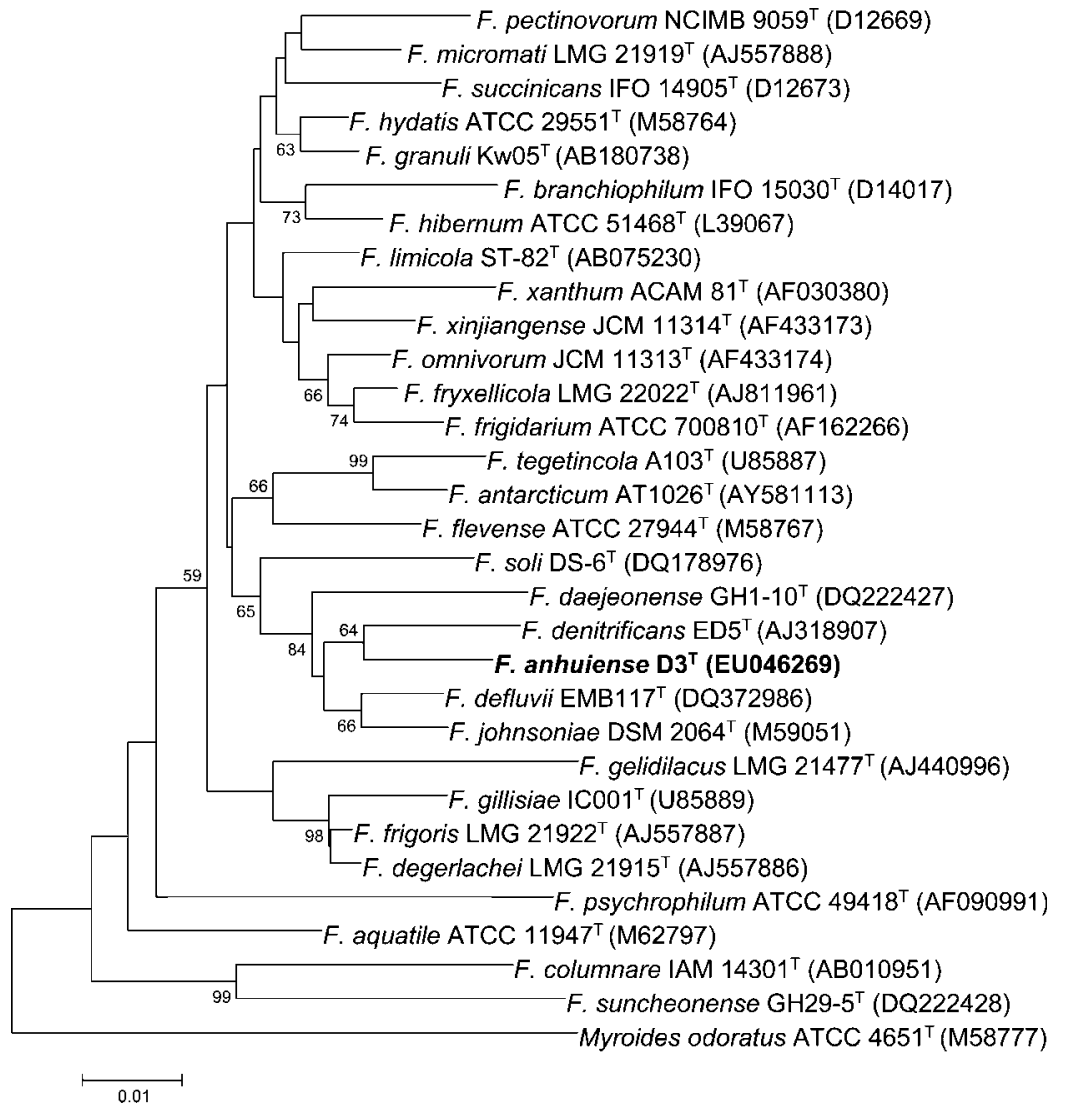

Fig. 1. Comparative analysis of the $16 \mathrm{~S}$ rRNA gene sequences of strain $\mathrm{D} 3^{\top}$ and representative strains of the genus Flavobacterium, using the neighbour-joining method. Bootstrap values (expressed as percentages of 1000 replications) $>50 \%$ are shown at branching points. The maximum-likelihood tree showed essentially the same topology (data not shown). Bar, 0.01 substitutions per nucleotide position.
Flavobacterium denitrificans, Flavobacterium johnsoniae, Flavobacterium daejeonense and Flavobacterium soli, respectively, and $<94.0 \%$ similarity with all other Flavobacterium species. 16S rRNA gene sequence similarity values $<97 \%$ have been proposed by Stackebrandt \& Goebel (1994) as a criterion for differentiating bacteria at the species level. The levels of 16S rRNA gene sequence similarity for strain $\mathrm{D} 3^{\mathrm{T}}$ demonstrate clearly that this isolate should be regarded as a novel species.

Morphological features were examined by using light microscopy and transmission electron microscopy (7650; Hitachi) as described by Nedashkovskaya et al. (2005). Growth was assessed at $4,5,10,25,30,35,37$ and $40{ }^{\circ} \mathrm{C}$ on $\mathrm{LB}$ agar. $\mathrm{NaCl}$ and $\mathrm{pH}$ tolerance were tested by using $\mathrm{LB}$ broth containing $0,1,2,3$ and $5 \% \mathrm{NaCl}$ or adjusted to $\mathrm{pH} 2.0-12.0$ (using increments of $1 \mathrm{pH}$ unit) according to Zhou et al. (2007). Growth was evaluated on cetrimide agar, Simmons' citrate agar, trypticase soy agar, MacConkey agar and nutrient agar. All tests were incubated at $30{ }^{\circ} \mathrm{C}$ for 2 days. Gram staining, endospore staining and flagellum staining were performed according to the methods described by Gerhardt et al. (1994). Oxidase activity was tested by determining the oxidation of $1 \%(\mathrm{w} / \mathrm{v})$ tetramethyl-p-phenylenediamine (Merck) and catalase activity was evaluated by determining the production of oxygen bubbles in a $5 \%(\mathrm{v} / \mathrm{v})$ aqueous hydrogen peroxide solution. Gliding motility, the production of flexirubin-type pigments and the adsorption of Congo red by colonies were investigated by following the minimal standards for the description of novel taxa in the family Flavobacteriaceae (Bernardet et al., 2002). Acid production from carbohydrates was determined by using the medium and method described by Yamaguchi \& Yokoe (2000). Carbon-source utilization was assessed by using a slightly modified ammonium salt medium $\left[0.2 \%\left(\mathrm{NH}_{4}\right)_{2} \mathrm{SO}_{4}\right.$, $0.05 \% \quad \mathrm{NaH}_{2} \mathrm{PO}_{4} \cdot \mathrm{H}_{2} \mathrm{O}, \quad 0.02 \% \quad \mathrm{MgSO}_{4} .7 \mathrm{H}_{2} \mathrm{O}, \quad 0.01 \%$ $\mathrm{CaCl}_{2} \cdot 2 \mathrm{H}_{2} \mathrm{O}$ and $\left.0.05 \% \mathrm{~K}_{2} \mathrm{HPO}_{4}\right]$ containing $1 \%$ carbon source. Hydrolysis of agar, Tween 80, Tween 20 and CMcellulose was investigated on LB agar after 2 days incubation according to Lanyi (1987) and Gerhardt et al. (1994). Urease activity and hydrolysis of casein, gelatin, aesculin, tyrosine and starch were determined as described by Cowan \& Steel (1965). Hydrolysis of chitin and pectin was tested according to Reichenbach \& Dworkin (1981) and Hildebrand (1971), respectively. Nitrate reduction was determined according to the method of Lanyi (1987). Additional enzymic activities and biochemical features were tested by using API ZYM and API 20E kits (bioMérieux) incubated at $30{ }^{\circ} \mathrm{C}$ for 2 days. Antibioticsensitivity tests were performed by using the diffusion method, as described by Park et al. (2007), on LB agar at $30{ }^{\circ} \mathrm{C}$ with filter-paper discs $(8 \mathrm{~mm}$ diameter; Sanofi Pasteur) containing the following antibiotics ( $\mu \mathrm{g}$, unless indicated otherwise): streptomycin (10), penicillin G (10 IU), ampicillin (10), chloramphenicol (30), erythro- 
mycin (15), tetracycline (30), ofloxacin (5), amoxicillin (10), cefazolin (30), rifampicin (5), gentamicin (10), ceftazidime (30), vancomycin (30), kanamycin (30), carbenicillin (100) and polymyxin B (30). After 2 days incubation, the diameters of the inhibition zones were measured. Phenotypic characteristics of strain $\mathrm{D} 3^{\mathrm{T}}$ are given in the species description and in Table 1 . Transmission electron micrographs of cells are shown in Supplementary Fig. S1 (available in IJSEM Online). Staining with India ink suggested that the layer surrounding the bacterial cell shown in Supplementary Fig. S1(a) represents capsular material.

Isoprenoid quinone analysis was performed according to Komagata \& Suzuki (1987), using cells harvested from an LB broth culture incubated at $30{ }^{\circ} \mathrm{C}$ for 2 days. The predominant isoprenoid quinone was MK-6, which is in line with all other members of the family Flavobacteriaceae. For quantitative analysis of the cellular fatty acid composition, a loopful of cell mass was harvested from an LB agar plate incubated at $30^{\circ} \mathrm{C}$ for 2 days and fatty acid methyl esters were prepared and identified by following the instructions of the Microbial Identification system (MIDI), as described by Sasser (1990). The major fatty acids found are listed in Table 2 and compared with those of the type strains of phylogenetically related Flavobacterium species. The cellular fatty acids mainly comprised iso- $\mathrm{C}_{15: 0}$, summed feature $3\left(\mathrm{C}_{16: 1} \omega 7 c\right.$ and/or iso- $\left.\mathrm{C}_{15: 0} 2-\mathrm{OH}\right)$ and $\mathrm{C}_{16: 0}$, in agreement with the profiles for most Flavobacterium species.
Genomic DNA was extracted and purified according to Yoon et al. (1996) and the DNA G+C content was determined by using the thermal-denaturation method (Mandel \& Marmur, 1968). The G $+\mathrm{C}$ content of the DNA was found to be $31.4 \mathrm{~mol} \%$. The description of novel Flavobacterium species has progressively expanded the range of DNA $\mathrm{G}+\mathrm{C}$ contents for the genus from 32$37 \mathrm{~mol} \%$ (Bernardet et al., 1996) to 30-41 mol\%.

Hence, phenotypic and phylogenetic data support the description of strain $\mathrm{D}^{\mathrm{T}}$ as the type strain of a novel species within the genus Flavobacterium, for which the name Flavobacterium anhuiense sp. nov. is proposed.

\section{Description of Flavobacterium anhuiense sp. nov.}

Flavobacterium anhuiense (an.hui.en'se. N.L. neut. adj. anhuiense pertaining to Anhui, the province where the type strain was isolated).

Cells are Gram-negative, non-spore-forming, aerobic rods, $1.0-2.5 \mu \mathrm{m}$ in length and $0.2-0.4 \mu \mathrm{m}$ in width and motile by gliding. Each cells is surrounded by a layer of capsular material. Colonies are yellow, circular and smooth with entire margins. Grows at $5-37{ }^{\circ} \mathrm{C}$ (optimum, $25-30{ }^{\circ} \mathrm{C}$ ), at $\mathrm{pH} 4.0-10.0$ (optimum, $\mathrm{pH} 6.0-8.0$ ) and with $0-2 \% \mathrm{NaCl}$ (optimum, $0-1 \%$ ). Growth occurs on trypticase-soy agar, nutrient agar and cetrimide agar, but not on Simmons' citrate agar or MacConkey agar. Congo red is not adsorbed by colonies. Flexirubin-type pigments are produced. Catalase, ornithine decarboxylase, lysine decarboxylase

Table 1. Differential characteristics of strain $\mathrm{D} 3^{\top}$ and related Flavobacterium species

Strains: 1, D3 ${ }^{\mathrm{T}}$; 2, F. defluvii DSM $17963^{\mathrm{T}}$ (Park et al., 2007); 3, F. denitrificans DSM 15936 ${ }^{\mathrm{T}}$ (Horn et al., 2005); 4, F. johnsoniae DSM 2064 ${ }^{\mathrm{T}}$ (Bernardet et al., 1996); 5, F. daejeonense DSM 17708 ${ }^{\mathrm{T}}$ (Kim et al., 2006); 6, F. soli KCTC $12542^{\mathrm{T}}$ (Yoon et al., 2006). +, Positive result; (+), weak or delayed reaction; -, negative result; $\mathrm{v}$, results vary between references; ND, no data available.

\begin{tabular}{|c|c|c|c|c|c|c|}
\hline Characteristic & 1 & 2 & 3 & 4 & 5 & 6 \\
\hline Maximum growth temperature $\left({ }^{\circ} \mathrm{C}\right)$ & 37 & 40 & 30 & $<37$ & 35 & 33 \\
\hline Tolerance of $2 \% \mathrm{NaCl}$ & + & - & + & - & + & + \\
\hline pH range for growth & $4-10$ & $5-10$ & $5.5-8.2$ & ND & $6-8$ & $6.5-8.5$ \\
\hline Gliding motility & + & + & + & + & + & - \\
\hline Flexirubin pigments & + & + & + & + & - & - \\
\hline Acid from carbohydrates & + & + & - & + & + & - \\
\hline \multicolumn{7}{|l|}{ Degradation of: } \\
\hline Pectin & - & $\mathrm{ND}$ & + & + & - & $\mathrm{ND}$ \\
\hline Gelatin & - & + & + & + & - & + \\
\hline Casein & + & + & + & + & - & - \\
\hline Starch & + & - & + & + & + & - \\
\hline CM-cellulose & - & + & ND & + & - & - \\
\hline Aesculin & + & + & ND & + & + & - \\
\hline Tyrosine & + & + & + & + & - & - \\
\hline DNA & - & ND & $\mathrm{ND}$ & + & - & - \\
\hline$\beta$-Galactosidase activity & + & $(+)$ & ND & + & + & - \\
\hline Oxidase activity & - & - & - & + & - & + \\
\hline Nitrate reduction & - & - & + & $\mathrm{v}$ & + & - \\
\hline DNA G $+C$ content $(\mathrm{mol} \%)$ & 31.4 & 33.5 & 34.6 & 35.2 & 35 & 36.9 \\
\hline
\end{tabular}


Table 2. Fatty acid contents (\%) of strain $\mathrm{D} 3^{\top}$ and the type strains of phylogenetically related species of the genus Flavobacterium

Strains: 1, D3 ${ }^{\mathrm{T}}$; 2, F. defluvii DSM $17963^{\mathrm{T}}$ (Park et al., 2007); 3, F. denitrificans DSM $15936^{\mathrm{T}}$ (Cousin et al., 2007); 4, F. johnsoniae DSM $2064^{\mathrm{T}}$ (Bernardet et al., 1996); 5, F. daejeonense DSM $17708^{\mathrm{T}}$ (Kim et al., 2006); 6, F. soli KCTC $12542^{\mathrm{T}}$ (Yoon et al., 2006). Fatty acids amounting to $<1 \%$ in all strains tested are not listed. tr, Trace amount $(<1.0 \%)$; ND, not detected.

\begin{tabular}{|c|c|c|c|c|c|c|}
\hline Fatty acid & 1 & 2 & 3 & 4 & 5 & 6 \\
\hline iso- $\mathrm{C}_{14: 0}$ & $\operatorname{tr}$ & $\operatorname{tr}$ & $\operatorname{tr}$ & 1.5 & $\operatorname{tr}$ & ND \\
\hline $\mathrm{C}_{14: 0}$ & 1.6 & $\mathrm{ND}$ & $\operatorname{tr}$ & $\mathrm{ND}$ & 1.2 & ND \\
\hline $\mathrm{C}_{15: 1} \omega 6 c$ & $\operatorname{tr}$ & $\operatorname{tr}$ & 3.8 & 1.3 & 2.7 & 1.9 \\
\hline iso- $\mathrm{C}_{15: 1} \mathrm{G}$ & 2.2 & 7.6 & 5.4 & 4.9 & 3.9 & 6.3 \\
\hline iso- $\mathrm{C}_{15: 0}$ & 28.2 & 19.8 & 21.8 & 24.9 & 23.0 & 26.6 \\
\hline anteiso- $\mathrm{C}_{15: 0}$ & 3.8 & 4.4 & 2.1 & 3.4 & 6.3 & 2.7 \\
\hline $\mathrm{C}_{15: 0}$ & 3.4 & 6.4 & 7.1 & 6.1 & $\mathrm{ND}$ & 8.2 \\
\hline iso- $\mathrm{C}_{16: 0}$ & $\operatorname{tr}$ & 2.3 & $\operatorname{tr}$ & 3.4 & 1.1 & 4.1 \\
\hline $\mathrm{C}_{16: 0}$ & 11.3 & 1.9 & 1.4 & 2.7 & 5.4 & 2.0 \\
\hline $\mathrm{C}_{17: 1} \omega 8 c$ & $\operatorname{tr}$ & $\operatorname{tr}$ & 1.3 & ND & 1.0 & 1.1 \\
\hline $\mathrm{C}_{17: 1} \omega 6 c$ & $\operatorname{tr}$ & 2.4 & 4.2 & 2.2 & 1.9 & 1.4 \\
\hline iso- $\mathrm{C}_{17: 1} \omega 9 c$ & 3.0 & 2.3 & 13.5 & 2.4 & 1.5 & 9.6 \\
\hline iso- $\mathrm{C}_{15: 0} 3-\mathrm{OH}$ & 6.0 & 11.2 & 6.8 & 6.6 & 6.2 & 6.0 \\
\hline iso- $\mathrm{C}_{16: 0} 3-\mathrm{OH}$ & 1.6 & 5.6 & 1.1 & 4.4 & 2.1 & 2.5 \\
\hline $\mathrm{C}_{16: 0} 3-\mathrm{OH}$ & 5.1 & 4.5 & 0.9 & 4.7 & 5.1 & $\mathrm{ND}$ \\
\hline iso- $\mathrm{C}_{17: 0} 3-\mathrm{OH}$ & 8.0 & 13.1 & 11.3 & 9.4 & 10.7 & 11.5 \\
\hline $\mathrm{C}_{17: 0} 3-\mathrm{OH}$ & $\operatorname{tr}$ & 1.0 & $\operatorname{tr}$ & $\mathrm{ND}$ & $\mathrm{tr}$ & $\mathrm{ND}$ \\
\hline Summed feature $3^{*}$ & 11.9 & 10.1 & 10.9 & 12.8 & 20.5 & 6.0 \\
\hline
\end{tabular}

*Summed feature 3 comprises iso- $\mathrm{C}_{15: 0} 2-\mathrm{OH}$ and/or $\mathrm{C}_{16: 1} \omega 7 c$ that could not be separated by GLC with the MIDI system.

and arginine dihydrolase activities are present. Oxidase, methyl $\alpha$-D-glucosidase, phenylalanine deaminase, arginine decarboxylase, DNase and urease activities are absent. Starch and casein are hydrolysed, but gelatin, pectin, chitin, Tween 20, Tween 80, agar and CM-cellulose are not. Acid is produced from D-glucose, L-fucose, L-rhamnose and amygdalin, but not from adonitol, D-arabinose, cellobiose, dulcitol, D-galactose, inositol, D-lactose, D-mannitol, melezitose, melibiose, raffinose, D-sorbitol or sucrose. Utilizes D-xylose, maltose, D-fructose, D-glucose, D-lactose, sucrose, L-sorbose, D-arabinose, salicin, raffinose, cellobiose, xylitol, melibiose, D-galactose and dextrin, but does not utilize erythritol, L-arabitol, D-ribose, D-sorbitol, D-mannose, inositol, adonitol, D-mannitol, inulin, turanose, citrate, acetate, D-erythrose, malonate, melezitose or tartrate. Nitrate is not reduced. Negative for indole and $\mathrm{H}_{2} \mathrm{~S}$ production and in the methyl red and Voges-Proskauer reactions (API 20E). In the API ZYM system, alkaline phosphatase, esterase lipase (C8), leucine arylamidase, valine arylamidase, acid phosphatase, naphthol-AS-BIphosphohydrolase and $\beta$-galactosidase activities are present, but lipase (C14), cystine arylamidase, trypsin, $\alpha$-chymotrypsin, $\alpha$-galactosidase, $\beta$-glucuronidase, $\beta$-glucosidase, $\alpha$-mannosidase and $\alpha$-fucosidase activities are absent. Weak enzymic activities are observed for esterase (C4), $N$-acetyl- $\beta$-glucosaminidase and $\alpha$-glucosidase. Resistant to gentamicin, ceftazidime, vancomycin, kanamycin, carbenicillin and polymyxin $\mathrm{B}$, but sensitive to streptomycin, penicillin G, ampicillin, chloramphenicol, erythromycin, tetracycline, ofloxacin, amoxicillin, cefazolin and rifampicin. MK-6 is the major isoprenoid quinone. The major fatty acids are iso- $\mathrm{C}_{15: 0}(28.2 \%)$, summed feature $3\left(\mathrm{C}_{16: 1} \omega 7 c\right.$ and/or iso- $\left.\mathrm{C}_{15: 0} 2-\mathrm{OH}, 11.9 \%\right)$ and $\mathrm{C}_{16: 0}(11.3 \%)$. The DNA G $+\mathrm{C}$ content is $31.4 \mathrm{~mol} \%$.

The type strain, $3^{\mathrm{T}}\left(=\right.$ KCTC $22128^{\mathrm{T}}=$ CGMCC $1.6859^{\mathrm{T}}$ ), was isolated from a soil sample from Anhui Province, PR China.

\section{Acknowledgements}

We are grateful for the financial support of the Chinese National Natural Science Foundation (30600001) and the Jiangsu Natural Sciences Foundation (BK2005422). We are also grateful to Che Ok Jeon for technical assistance.

\section{References}

Bergey, D. H., Harrison, F. C., Breed, R. S., Hammer, B. W. \& Huntoon, F. M. (1923). Genus II. Flavobacterium gen. nov. In Bergey's Manual of Determinative Bacteriology, pp. 97-117. Baltimore: Williams \& Wilkins.

Bernardet, J.-F. \& Bowman, J. P. (2006). The genus Flavobacterium. In The Prokaryotes: a Handbook on the Biology of Bacteria, 3rd edn, vol. 7, pp. 481-531. Edited by M. Dworkin, S. Falkow, E. Rosenberg, K. H. Schleifer \& E. Stackebrandt.

Bernardet, J.-F., Segers, P., Vancanneyt, M., Berthe, F., Kersters, K. \& Vandamme, P. (1996). Cutting a Gordian knot: emended classification and description of the genus Flavobacterium, emended description of the family Flavobacteriaceae, and proposal of Flavobacterium hydatis nom. nov. (basonym, Cytophaga aquatilis Strohl and Tait 1978). Int J Syst Bacteriol 46, 128-148.

Bernardet, J.-F., Nakagawa, Y. \& Holmes, B. (2002). Proposed minimal standards for describing new taxa of the family Flavobacteriaceae and emended description of the family. Int J Syst Evol Microbiol 52, 1049-1070.

Brosius, J., Palmer, J. L., Kennedy, J. P. \& Noller, H. F. (1978). Complete nucleotide sequence of $16 \mathrm{~S}$ ribosomal RNA gene from Escherichia coli. Proc Natl Acad Sci U S A 75, 4801-4805.

Cousin, S., Päuker, O. \& Stackebrandt, E. (2007). Flavobacterium aquidurense sp. nov. and Flavobacterium hercynium sp. nov., from a hard-water creek. Int J Syst Evol Microbiol 57, 243-249.

Cowan, S. T. \& Steel, K. J. (1965). Manual for the Identification of Medical Bacteria. London: Cambridge University Press.

Felsenstein, J. (1981). Evolutionary trees from DNA sequences: a maximum likelihood approach. J Mol Evol 17, 368-376.

Felsenstein, J. (1985). Confidence limits on phylogenies: an approach using the bootstrap. Evolution 39, 783-791.

Felsenstein, J. (1993). PHYLIP (phylogeny inference package), version 3.5c. Distributed by the author. Department of Genome Sciences, University of Washington, Seattle, USA.

Gerhardt, P., Murray, R. G. E., Wood, W. A. \& Krieg, N. R. (1994). Phenotypic characterization. In Methods for General and Molecular Bacteriology, pp. 607-654. Edited by P. Gerhardt. Washington, DC: American Society for Microbiology. 
Hildebrand, D. C. (1971). Pectate and pectin gels for differentiation of Pseudomonas sp. and other bacterial plant pathogens. Phytopathology 61, 1430-1436.

Horn, M. A., Ihssen, J., Matthies, C., Schramm, A., Acker, G. \& Drake, H. L. (2005). Dechloromonas denitrificans sp. nov., Flavobacterium denitrificans sp. nov., Paenibacillus anaericanus sp. nov. and Paenibacillus terrae strain $\mathrm{MH} 72, \mathrm{~N}_{2} \mathrm{O}$-producing bacteria isolated from the gut of the earthworm Aporrectodea caliginosa. Int J Syst Evol Microbiol 55, 1255-1265.

Kim, B.-Y., Weon, H.-Y., Cousin, S., Yoo, S.-H., Kwon, S.-W., Go, S.-J. \& Stackebrandt, E. (2006). Flavobacterium daejeonense sp. nov. and Flavobacterium suncheonense sp. nov., isolated from greenhouse soils in Korea. Int J Syst Evol Microbiol 56, 1645-1649.

Kimura, M. (1980). A simple method for estimating evolutionary rates of base substitutions through comparative studies of nucleotide sequences. J Mol Evol 16, 111-120.

Kimura, M. (1983). The Neutral Theory of Molecular Evolution. Cambridge: Cambridge University Press.

Komagata, K. \& Suzuki, K. (1987). Lipid and cell-wall analysis in bacterial systematics. Methods Microbiol 19, 161-207.

Kumar, S., Tamura, K., Jakobsen, I.-B. \& Nei, M. (2001). MEGA2: molecular evolutionary genetics analysis software. Bioinformatics 17, 1244-1245.

Lanyi, B. (1987). Classical and rapid identification methods for medically important bacteria. Methods Microbiol 19, 1-67.

Ludwig, W. \& Klenk, H.-P. (2001). Overview: a phylogenetic backbone and taxonomic framework for procaryotic systematics. In Bergey's Manual of Systematic Bacteriology, 2nd edn, vol. 1, pp. 49-65. Edited by D. R. Boone, R. W. Castenholz \& G. M. Garrity. New York: Springer.

Mandel, M. \& Marmur, J. (1968). Use of ultraviolet absorbancetemperature profile for determining the guanine plus cytosine content of DNA. Methods Enzymol 12B, 195-206.

Nedashkovskaya, O. I., Kim, S. B., Suzuki, M., Shevchenko, L. S., Lee, M. S., Lee, K. H., Park, M. S., Frolova, G. M., Oh, H. W. \& other authors (2005). Pontibacter actiniarum gen. nov., sp. nov., a novel member of the phylum 'Bacteroidetes', and proposal of Reichenbachiella gen. nov. as a replacement for the illegitimate prokaryotic generic name Reichenbachia Nedashkovskaya et al. 2003. Int J Syst Evol Microbiol 55, 2583-2588.
Park, M., Ryu, S. H., Thi Vu, T.-H., Ro, H.-S., Yun, P.-Y. \& Jeon, C. O. (2007). Flavobacterium defluvii sp. nov., isolated from activated sludge. Int J Syst Evol Microbiol 57, 233-237.

Reichenbach, H. \& Dworkin, M. (1981). Introduction to the gliding bacteria. In The Prokaryotes, vol. 1, pp. 315-327. Edited by M. P. Starr, H. Stolp, H. G. Trüper, A. Balows \& H. G. Schlegel. Berlin: Springer.

Saitou, N. \& Nei, M. (1987). The neighbor-joining method: a new method for reconstructing phylogenetic trees. Mol Biol Evol 4, 406-425.

Sasser, M. (1990). Identification of bacteria by gas chromatography of cellular fatty acids. USFCC Newsl 20, 16.

Stackebrandt, E. \& Goebel, B. M. (1994). Taxonomic note: a place for DNA-DNA reassociation and 16S rRNA sequence analysis in the present species definition in bacteriology. Int J Syst Bacteriol 44, 846-849.

Thompson, J. D., Gibson, T. J., Plewniak, F., Jeanmougin, F. \& Higgins, D. G. (1997). The CLUSTAL_X windows interface: flexible strategies for multiple sequence alignment aided by quality analysis tools. Nucleic Acids Res 25, 4876-4888.

Weon, H.-Y., Song, M.-H., Son, J.-A., Kim, B.-Y., Kwon, S.-W., Go, S.-J. \& Stackebrandt, E. (2007). Flavobacterium terrae sp. nov. and Flavobacterium cucumis sp. nov., isolated from greenhouse soil. Int $J$ Syst Evol Microbiol 57, 1594-1598.

Yamaguchi, S. \& Yokoe, M. (2000). A novel protein-deamidating enzyme from Chryseobacterium proteolyticum sp. nov., a newly isolated bacterium from soil. Appl Environ Microbiol 66, 3337-3343.

Yoon, J.-H., Kim, H., Kim, S.-B., Kim, H.-J., Kim, W. Y., Lee, S. T., Goodfellow, M. \& Park, Y.-H. (1996). Identification of Saccharomonospora strains by the use of genomic DNA fragments and rRNA gene probes. Int J Syst Bacteriol 46, 502-505.

Yoon, J.-H., Kang, S.-J. \& Oh, T.-K. (2006). Flavobacterium soli sp. nov., isolated from soil. Int J Syst Evol Microbiol 56, 997-1000.

Yoon, J.-H., Kang, S.-J., Lee, J.-S. \& Oh, T.-K. (2007). Flavobacterium terrigena sp. nov., isolated from soil. Int J Syst Evol Microbiol 57, 947-950.

Zhou, Y., Wang, X., Liu, H., Zhang, K.-Y., Zhang, Y.-O., Lai, R. \& Li, W.-J. (2007). Pontibacter akesuensis sp. nov., isolated from a desert soil in China. Int J Syst Evol Microbiol 57, 321-325. 